\title{
A NEW GENERALIZATION OF GRÜSS INEQUALITY IN INNER PRODUCT SPACES
}

\author{
NENAD UJEVIĆ
}

Abstract. A new generalization of Grüss inequality in real inner product spaces is derived. Applications to Lebesgue integrals are given.

Mathematics subject classification (2000): 26D15, 46C05.

Key words and phrases: Grüss inequality, generalization, inner product space, Lebesgue integrals.

\section{REFERENCES}

[1] P. Cerone, S. S. Dragomir AND J. Roumeliotis, An inequality of Ostrowski-Grüss type for twice differentiable mappings and applications in numerical integration, Kyungpook Math. J., 39 (2) (1999), 331-341.

[2] S. S. DRAGOMIR, A generalization of Grüss inequality in inner product spaces and applications, J. Math. Anal. Appl., 237 (1999), 74-82.

[3] S. S. DRAGOMIR, Grüss inequality in inner product spaces, Austral. Math. Soc. Gaz., 26 (2) (1999), 66-70.

[4] S. S. DRAGOMIR AND A. MCANDREW, On trapezoid inequality via a Grüss type result and applications, Tamkang J. Math., 31 (3) (2000), 193-201.

[5] S. S. DRAGOMIR AND S. WANG, An Inequality of Ostrowski-Grüss Type and Its Applications to the Estimation of Error Bounds for Some Special Means and Some Numerical Quadrature Rules, Comput. Math. Appl., 33 (1997), 15-20.

[6] A. A. KIRYLOV AND A. D. GVISHIANY, Theorems and problems of functional analysis, Nauka, Moscow, 1979.

[7] M. Matić, J. PeČARIĆ AND N. UjeVIĆ, Improvement and Further Generalization of Some Inequalities of Ostrowski-Grüss Type, Comput. Math. Appl., 39 (2000), 161-179.

[8] D. S. Mitrinović, J. E. PeČArić And A. M. FinK, Inequalities Involving Functions and Their Integrals and Derivatives, Kluwer Acad. Publ., Dordrecht/Boston/Lancaster/Tokyo, 1991.

[9] D. S. Mitrinović, J. E. PeČARIĆ AND A. M. FinK, Classical and New Inequalities in Analysis, Kluwer Acad. Publ., Dordrecht/Boston/Lancaster/Tokyo, 1993.

[10] C. E. M. PEARCE, J. PeČARIĆ, N. Ujević AND S. VARošAneC, Generalizations of Some Inequalities of Ostrowski-Grüss Type, Math. Inequal. Appl., Vol 3, No 1, 2000, 25-34. 